\title{
The Role of “16+1" Jingchu Culture “Walk Out” Walks: The Case of Macedonia
}

\author{
Frosina Vitkovska ${ }^{a}{ }^{*}$, Laijin Shen ${ }^{b}$ \\ Department of Humanities and Law, Wuhan University of Technology, Wuhan, China \\ a1364031138@qq.com , b1106548263@qq.com
}

Keywords: “16+1”, Jingchu culture, “Walk Out”, Macedonia

\begin{abstract}
Chinese president Xi Jinping release “The Dream of China” and lunched the rebirth of the Silk Road and right then in that very moment changed the course of the world; and that was the turning moment of a new page of the world's history and the entering in the new era of the world's civilization in whole where modern diplomacy is not any longer based only on politic and economy, but on culture as the unique representative distinguishing one another; only welcomed by one another is showing the true light of a nation's soul, the true value, its selfconfidence and the reasons for it. The "16+1" Mechanism and the China - CEEC Coordination Center for Cultural Cooperation established in its frame in Macedonia are ones of the platforms that come out of the One Belt One Road Initiative for cooperation of China with the sixteen Central and Eastern Europe countries. Being Hubei's "Image of China" and its "Visit card" to the world, Jingchu culture is the main link and bridge keeping the connection between Hubei and CEEC. This work is applying The " $16+1$ " Mechanism and the China - CEEC Coordination Center for Cultural Cooperation in the Jingchu culture "Walk Out" as the main and most important and safest mediums for showcasing and spreading the mesmerizing beauty of Hubei culture and for sowing the seeds of Jingchu all along the ways across these sixteen countries with the focus on Macedonia; and the hosts welcoming the culture of China's Hubei and the sixteen countries of Central and Eastern Europe and the main stages for telling and retelling "The Stories of China" and the main screens for showcasing the realization of "The Dream of China" by carrying the spirit for a joined world of harmony and peace to CEEC that will give a birth to a better and flourishing multifield exchange and cooperation between Hubei and Macedonia and will play a leading role for the upgrading of Hubei's international image and its international influence in those countries and for increasing their economic level to a higher pedestal of expanded development.
\end{abstract}

\section{Introduction}

"Culture is the blood of a nation"[5] that keeps it alive; is the cradle of the all material and spiritual wealth accumulated in the long history of a nation development; in its background are engraved all the political, economic and social relationship of a country; it's an immortal value keeping on the existence of a nation carved all along the centuries by protecting its dignity; it's the unique embodiment of a nation carrying on the message of its predecessors, despite all the political, economic, social changes limited by the times, still keeping on its uniqueness and its true voice the voice of its people. Walking backwards the history prior the first centuries BC from nowadays Xian the world heard the voice of China that continued echoing to the very far West along the longest route on earth traced by the traders, the pilgrims, the warriors, delivering the message of its silk for a joined world of peace and harmony. 2013 the Chinese president Xi Jinping lunched the rebirth of the same road of its silk and tuned on the echoing voice of "The Stories of China"; by releasing "The Dream of China" changed the course of the world to a new path of the mankind history "where modern diplomacy is not any longer based only on politic and economy, but on culture as the unique representative distinguishing one another"[3]. "The Ancient Silk Road opened a new window for friendly exchanges between countries, wrote a new chapter for the human progress and development and accumulated the silk road spirit featuring peace and cooperation, openness and inclusiveness, mutual learning and mutual benefit and win-win results that remains a 
precious heritage of the human civilization."[5]

“To become rich, first you must build a road!”[5] said president Xi 2013 when pressing the reanimation button of the Silk Road launched the One Belt One Road Initiative (hereinafter BRI). At the 19th National Congress of Communist Party of China (hereinafter CPC), president Xi emphasized "we should pursue the Belt and Road Initiative as a priority, give equal emphasis to "bringing in" and "going global", follow the principle of achieving shared growth through discussion and collaboration, and increase openness and cooperation in building innovation capacity and to keep on building the BRI into a road of peace, a road of prosperity, a road of opening up, a road of innovation"[5].

The "16+1" Mechanism and the China - CEEC Coordination Center for Cultural Cooperation established in its frame in Macedonia are ones of the platforms that come out of the BRI for cooperation of China with the sixteen Central and Eastern Europe countries (hereinafter CEEC). "Culture is the soul of BRI"[5] stated president $\mathrm{Xi}$, and Jingchu culture is the nucleus of the Chinese culture; is the spiritual power of Hubei province that is playing a leading role in the rejuvenation of China and the renaissance of the Chinese nation and the future of its people; it has left timeless trails to the world that have continued echoing all along the road of the silk up today and right in the future, causing the world to see the true value of the China's voice right there in its roots.

Macedonia is the pearl in the Balkans countries shell that has "historically played an important role in the relations between Europe and Asia since Alexander the Great"[1]; is "a true crossroads of cultures and history on the original Silk Road."[1] In the mid-19 century, the German politician Bismarck has said "the one who controls the Morava Vardar Valley, controls Europe"[1], and at the beginning of 20 century the Serbian Prime Minister Nikola Pašić pointed out "the one who controls Macedonia, controls the Balkans"[1].

"Taking the smell of the first ink on the first brush in the mankind history, the flavor of the first piece of paper, the sound of the first coin, the sounds of The Chimney Bells of Chu, the shines of the first sword and the first bronze castings, the mesmerizing beauty of the first silk weaved embroideries, the firsts lacquer works, using the first compass of Chu, enriched by the wisdom of Laozhuang's philosophy, following the flight of the phoenix and carry on its spirit for a joined world of harmony and peace"[3] is the first attempt for bringing the Jingchu culture "Walk Out" walks to Macedonia. Applying the " $16+1$ " Mechanism and the China - CEEC Coordination Center for Cultural Cooperation will assure the continuous dialogue between Hubei and Macedonia as the main stages for welcoming their cultures. Enhancing the Jingchu culture "Walk Out" in Macedonia will give a birth to a better and flourishing multifield exchange and cooperation between Hubei and Macedonia; will give a play as an important support in the collaboration between Hubei and CEEC and will play a leading role for the upgrading of China's international image and its international influence in those countries and for increasing their economic level to a higher pedestal of expanded development.

\section{Jingchu Culture and Its Silk Road “Walk Out” Walks}

Rooted back deeper than three thousand years in the history, "named by the State of Chu and the Chu people"[3] Jingchu culture "at first was a local culture that was rising in the Han River region from West Zhou dynasty (1066 - 256BC) to Spring and Autumn Period (770 - 476BC)”[3] after on "the Chu people have developed in a distinctive local southern multicomponent culture in the Jianghan region”[3]; "it enjoys age long history, abundant connotation, unique local characteristics and huge potential for economic and cultural exploitation."[3] "The First Bronze Smelting and Casting in the history of mankind, The First Silk Embroidery Weavings, The First Wood-bamboo Lacquer Works, The Chu Art and Music and the sounds of the worldwide known Bianzhong or The Chimney Bells of Chu, The Laozi and Zhuangzi philosophy and Quyuan's Literature"[3] are "the eight main pillars of Chu culture that has reached the peak of the culture development in the history of the human civilization"[3] and the firmest foundation of the Silk Road. Its four spiritual characteristics: "The spirit for forging ahead with hard work and self-improvement, The spirit for being enterprising and innovative, The spirit for embracing everything that is useful and The spirit 
for advocating armed and loving patriotism for the motherland"[3] are lying down on the base of $B R I$ and are being the main stream for driving on the world along the new path of the mankind history.

After the Chinese president Xi Jinping at the $18^{\text {th }}$ National Congress emphasized the importance of the self-confidence in the culture as a country's and a nation's soul and its importance as an essential, deep, lasting strength and the core for imprinting a new chapter of the national renaissance for the development of a country and its nation brighter future, Hubei Provincial Government and the Hubei Provincial Department of Culture have implemented various measures and included different approaches for boosting the Jingchu culture "Walk Out" walks along the Silk Road as its "Image of China" and its "Visit Card" to the world. In the latest years have been conducted and overtaken plenty of various projects by the experts engaged with the $B R I$ and scholars devoted to the carrying on the message of the Silk Road; under the platform "Jingchu Culture Walk Out" actively have been building foreign cultural exchange platforms, have been organizing and carrying out "Jingchu Culture Silk Road Journey" series of foreign cultural exchange activities for promoting the romantic charm of Jingchu culture tangible and intangible heritage beyond China and let Jingchu: Wudang wushu, Han embroidery, dough sculpture, Wuhan puppet show, Wuhan paper-cut, Wuhan acrobatics, traditional drama, folklore, folk arts, literature, customs, Quyuan's poetry, Mulan's legend, Han opera, Chu opera, Huangmei opera, the worldwide known Bianzhong or The Chimney Bells of Chu's sounds culture glory make their walks out there in the world.

\section{Jingchu Culture and Its “16+1" “Walk Out” Walks}

2018 marks the 6th year of cooperation between China and the Central and Eastern European countries. With the joint efforts of the 17 participants annually have been announced guidelines for cooperation and have been built platforms for exchanges in the fields of economy, trade, investment, culture, education, agriculture, transportation, tourism, science and technology, health, think tanks, local cooperation and youth. The "16+1" Mechanism has yielded fruitful achievements in the past five years and have continued to promote the development of the bilateral relations between China and the 16 Central and Eastern European countries. "The prospects for the CEEC have become encouraging because with the $16+1$ membership, which is a part of the B\&R Initiative, the entire region was given the opportunity to overcome mutual prejudices and to begin to build relations based on partnership and not exclusively on the competition."[1] which have leaded towards better understanding of each other, faster and more secure connectivity, fruitful exchanges and prosperity of the people. The General Secretary of the Central Committee of CPC Xi Jinping emphasized that "China is offering its knowledge and approach to solving the problems facing mankind."[4] "China Solutions means the path, the theory, the system, and the culture of socialism with Chinese characteristics have kept developing, blazing a new trail for other developing countries to achieve modernization."[4] “Throughout China's 30 plus years of opening and reform, it has constantly looked out at the world to see what the solutions are. But it's found again and again that the solutions are always in the room. It comes back to understanding local culture, and local mind set.”[4]

The strengthening Cultural and People-to-people Bonds was one of the main objective of the Twelve Measures that China put forward for promoting friendly cooperation with the CEEC at the $1^{\text {st }}$ Summit of China and Central and Eastern Europe Countries held in Warsaw, Poland in April 2012; has tightened the China- CEEC relationship bindings of the silk, remained since the very roots bridging the time and the distance in between the very far East and very far West lasting and unbreakable just like the silk in its nature - the strongest and untearable threat. Culture has been seen as the unique and the rightest language for keeping on the dialogue between China and CEEC ongoing and the main medium for carrying on the echoing of the message of the silk for a united world of peace and harmony, prosperity, flourishing and upgrading in all the fields, mutual growing in all the meanings in a world of shared future and mutual celebration of the win-win relationship. In the past five years the romantic charm or Jingchu has gained a new dimension for showing and 
sharing its glory. " $16+1$ " has become one of the main screens for showcasing the mesmerizing beauty of Hubei in which land have been cultivated the very roots of the culture of China where has begun the story of Jingchu and right from there has begun the telling of "The Stories of China".

The China - CEEC Ministerial Forums on Cultural Cooperation, the Chinese performing arts delegation visit of Lithuania, Latvia and Estonia (2013), their visit of Poland, the Czech Republic and Bulgaria (2014), the China-CEEC Arts Cooperation Forums, the CEECs curators of national museums of arts visit of China (2013), the CEECs artistic directors of international dance festivals and choreographers visit of China (2015), the Chinese Art Festival held in Lithuania, Estonia and Latvia (2015), the Chinese performing arts delegation visit of Hungary, Serbia and Romania (2015), the 1st China-CEEC Summer Dance Camp (2016, Shaanxi), the News Conference for the 2016 Year of China-CEEC People-to-People and Cultural Exchanges held in Beijing, the 1st China-CEEC Arts Cooperation Forum (2013, Beijing), the China-CEEC Dance Culture Union launched in Beijing Dance Academy (2016), the 1st China-CEEC Literature Forum (2016, Budapest), the 1st China-CEEC Cultural and Creative Industries Forum (2016, Belgrade), the Chinese performing arts delegation visit of Slovenia, Slovakia and Croatia (2016), the famous CEECs painters visit of Guizhou province (2016), the 2nd China-CEEC Summer Dance Camp (2016, Yunnan), the Beijing International Book Fair and the China-CEEC Translation Exhibition (2016, Beijing), the 1st China-CEEC Experts' Forum on Intangible Cultural Heritage (2016, Poland), the artistic directors of international opera festivals from CEECs visit of China (2016), the 1st Annual Meeting of ChinaCEEC Dance Culture Union (2016, Bulgaria), the Seminar on Sinology Research and Chinese Teaching in Central and Eastern European Countries (2016, Latvia), the China-CEEC Winter Dance Camp (2017, Shenzhen), the opening ceremony of China-CEEC Year of Media Cooperation and Film Exhibition of CEEC (2017, Beijing), the China-CEEC Association of Traditional Chinese Medicine setting up in Budapest (2017), the Annual Meeting of the China-CEEC Dance Culture Union (2017, Macedonia), the China-CEEC Cultural Season (2017), the 1st China-CEEC Cultural Heritage Forum (2017, Serbia), the 1st China-CEEC Music Camp (2017, Macedonia), the ChinaCEEC Music Academy Union and China-CEEC Arts Creation and Research Centre establishing in Zhejiang Conservatory of Music (2017), the launch of China-CEEC Libraries Union (2017), the directors of CEEC International Folk Art Festival visit of China (2017), the 1st Dance Master Workshop held in Beijing Dance Academy (2017), the "Martial Arts on the Silk Road" training sessions held in Hungary, Romania and Croatia (2017), the China-CEEC Education Policy Dialogue and the meeting of the China-CEEC Higher Education Institutes Consortium, the establishment of the China - CEEC Coordination Centre for Cultural Cooperation (2018, Macedonia), plenty of various workshops, symposiums, seminars, exhibitions and so on in the past five years have been the 'stages' produced by " $16+1$ " for welcoming the culture of China with the diversity of the culture beauty of these sixteen countries of Central and Eastern Europe; have been the main tools that have provided a pleasant climate for the blossoms of the buds of Jingchu in CEEC and the main mediums for telling "The Stories of China" - the message of the silk and the main forces for carrying on its power for keeping the world in a unity of harmony and peace beyond the time and the distance, which is the right and the must duty of the nowadays generations as the best rewards to our predecessors.

\section{Jingchu Culture and Its “Walk Out” Walks in Macedonia}

"Until recently in Macedonian society the notions and representations of Chinese culture have too often been mediated by Western literature and media which has led to the adoption of certain stereotypes about China and Chinese culture."[1] "Up today is not certainly known how deep in the history the roots of the Chinese and Macedonian cultures have met, but certainly is known their bindings have started prior the first century BC when the traders, pilgrims and warriors started their walking the greatest land route on earth, from the very far East of today China's Xian, following the road that has been traced and walked by the greatest commander and conqueror in the world Alexander the Great of Macedonia; all along to the Mediterranean region in the West."[2] Before its rebirth "on the path of the Silk Road Sinology has played the most important role in the spreading of 
the Chinese culture and language in Macedonia and in broadening the views in reflecting of one another's cultures. The Sinology in Macedonia has deepened the roots of the Chinese culture and language and has been the main nutritive source for growing the Chinese culture tree in Macedonia, which resulted to the establishment of the Confucius Institute and the birth of the first generation of Macedonian sinologists and their works."[2] China and Macedonia have long history and profound cultural background. In this period the both countries have carried out various kinds of cultural exchange activities with the aim of promoting the excellent cultures of the two countries. But in spite all the great achievements in so many fields of their collaboration, the Jingchu - Macedonia Culture page as yet remains a blank chapter on the path of the silk.

"Macedonia as a region is still catena mundi - links to which different cultures are attached, which are not tolerated in a traditional western European way and tradition, but exist together, in a harmonious coexistence."[1] "China is a relatively new actor in the region, which in terms of its disposition, perception of and actions in the region is nothing like other actors and stakeholders who have been previously involved in it." [1] This year is the $25^{\text {th }}$ anniversary of the jointly celebration of the People's Republic of China diplomatic ties with Macedonia. On the path of the Silk Road their walks on the silk have deepen their friendly and cooperative relations, have conducted close exchanges and cooperation in partly affairs, science and technology, culture at the top level that are continuing to expand.

Alike the Ancient Silk Road was not only one road, but a sublimation of routes the " $16+1$ " Mechanism, although a relatively new platform, has revealed new opportunities for sub-regional win-win cooperation and has been displaying different directions and ways for building a shared future. Along the implementation of the " $16+1$ " in the Balkans Chinese investments and big projects have continuing landing in this region and have deepened and boosted the bilateral collaboration with the countries in this region and with Macedonia as well; the local cooperation has gradually become the driving force to promote the economic and trade communication and people-to-people exchange.

"Today the world is facing with so many challenges and safety, economic and political risks. Nevertheless the culture still continues to remain one of the rare opened doors, a strength that unites and success to overcome the boundaries and the separations, that cares for the differences and promotes them in all the aspects." said the Minister of Culture of Republic of Macedonia Robert Alagjozovski at the opening ceremony of the China - CEEC Coordination Centre for Cultural Cooperation established in Macedonia after the signing of the Memorandum of Understanding between the Ministry of Culture of the People's Republic of China and the Ministries Responsible for Culture of Central and Eastern European Countries for Establishing the China - CEEC Coordination Centre for Cultural Cooperation in the Republic of Macedonia at the $3^{\text {rd }}$ Ministerial Forum on Cultural Cooperation in September 2017 in Hangzhou. This centre and the signing of the Macedonia- China Executive Program on Cultural Cooperation 2018-2013 has offered an excellent opportunity for Jingchu culture to make its "Walk Out" walks not only in Macedonia but to all the East and Central European countries; has provided firm platforms for wide-opening the doors for cooperation between Hubei and Macedonia, enabling regional connectivity and accelerated economic development and bind the ties of silk with the eleven EU countries and the other four Balkan countries; and thus to contribute for their more peaceful, stable and prosperous shared future win-win collaboration.

\section{Conclusion}

By giving apply of the " $16+1$ " Initiative and the China - CEEC Coordination Centre for Cultural Cooperation the Jingchu culture "Walk Out" walks will fill in the first chapter of the Jingchu culture - Macedonia book of the bilateral collaboration between Hubei and Macedonia; by carrying on "The spirit for forging ahead with hard work and self-improvement, The spirit for being enterprising and innovative, The spirit for embracing everything that is useful and The spirit for advocating armed and loving patriotism for the motherland" to those sixteen countries of Central and Eastern Europe will be telling "The Stories of China"; by sowing the seeds of Jingchu will 
become one of the "The Dream of China" realisation fragments of its glorious charm that will be worth of being reminisce right there from the shared future of Hubei and CEEC win-win cooperation, mutual understanding, multifield exchanges, growing together in all the meanings in a joined world of harmony, peace and prosperity - the testament of the road of the silk.

\section{References}

[1] Book of Proceedings China - CEEs 2017 (3-rd China - CEE Conference "The Role of Human Capital in the One Belt One Road Initiative”, Lake Ohrid - Macedonia: October 6 - 7, 2017)

[2] Vitkovska, F., Shen, L. (2018) From the Old Silk Road to the New Silk Road Era: Promoting of Chinese Culture in Republic of Macedonia, ISCCD2018

[3] Vitkovska, F., Shen, L. (2018) "16+1" Showcase of Jingchu Culture Self-confidence, ESSAEME2018

[4] China - CEEC Think Tanks Network http://16plus1-thinktank.com//index.html

[5] Database of President XI Jinping Series of Important Speeches http://jhsjk.people.cn/ 
